\title{
Traditional vegetable salad (ulam) of Borneo as source of functional food
}

\author{
${ }^{1,2}$ Awang-Kanak, F. and ${ }^{1,3, * A b u ~ B a k a r, ~ M . F . ~}$ \\ ${ }^{1}$ Faculty of Applied Sciences and Technology, Universiti Tun Hussein Onn Malaysia (UTHM), Hub \\ Pendidikan Tinggi Pagoh, KM1, Jalan Panchor, 84600, Muar, Johor, Malaysia \\ ${ }^{2}$ Preparatory Centre for Science and Technology, Universiti Malaysia Sabah, Jalan UMS, 88400, Kota \\ Kinabalu, Sabah, Malaysia \\ ${ }^{3}$ Center of Research for Sustainable Uses of Natural Resources, Faculty of Applied Sciences and \\ Technology, Universiti Tun Hussein Onn Malaysia (UTHM), Hub Pendidikan Tinggi Pagoh, KM1, Jalan \\ Panchor, 84600, Muar, Johor, Malaysia
}

Article history:

Received: 29 March 2019

Received in revised form: 11

June 2019

Accepted: 13 June 2019

Available Online: 8 July 2019

Keywords:

Borneo,

Traditional vegetable,

Ulam,

Functional food,

Health benefits

DOI:

https://doi.org/10.26656/fr.2017.4(1).138

\begin{abstract}
Traditional vegetable salad or "ulam" are shown to have beneficial properties for health maintenance and should be further studied and used as a source of food as well as medicine. Apparently, the fern species are highlighted common plants that have been consumed as traditional vegetable all around Borneo, especially Stenochlaena palustris or locally known as "lemiding" (Brunei), "lambiding" (Sabah), "midin" (Sarawak), and "kalakai" (Kalimantan). Stenochlaena palustris was also studied for its phenolic contents and antioxidant properties. The extract of the edible young sterile frond of Stenochlaena palustris contained more anthocyanins $(51.32 \mathrm{mg} / 100 \mathrm{~g}$ dry matter) compared to extracts of mature sterile, young fertile, and mature fertile fronds of the fern. The Penan people also used Stenochlaena palustris as herbal medicine to reduce high fever and served it to new mothers during the postpartum recovery period. Other fern species that have been cited used in Borneo are Diplazium esculentum, Nephrolepis acutifolia, and Nephrolepis bisserata. Fruit of Solanum torvum, leaves of Cosmos caudatus, the flower buds of Etlingera spp., young shoot of bamboo species, and banana inflorescence have been consumed as traditional vegetable in many parts of Borneo, the preparation being either fresh or used as a condiment in cooking. In previous literature also noted that seaweeds namely Kappahycus alvarezzii and Eucheuma denticulatum, as well as mushrooms like Termitomyces aurantiacus, have also been administered as traditional vegetable. It is scientifically shown that traditional vegetable from Borneo have potential as food that could bring health benefit to the consumer, especially in preventing oxidative damage related diseases, microbial infection, and metabolic disorder such as diabetes. Innovation on consumption method of traditional vegetable also suggested, for example, the traditional vegetable be developed into natural food products and food additive, e.g. herbal teas, essential oil.
\end{abstract}

\section{Introduction}

Borneo is the largest island with an area of 700,000 sq. $\mathrm{m}$ in Sunda Archipelago laid at the $4^{0} \mathrm{~S}$ to $7^{0} \mathrm{~N}$ of the equator; it is home for one of the largest forested area in South East Asia (Barton and Paz, 2007; Brodie and Giodarno, 2011). It also has a unique geographical setting with altitude mainly below $1000 \mathrm{~m}$, and the northern part of the island has a core with altitude ranging from $1000 \mathrm{~m}$ to $2000 \mathrm{~m}$ ASL (Barton and Paz, 2007). Politically, Borneo is made up three sovereign countries; Brunei Darussalam, Malaysia, and Indonesia
(Hitchner, 2010). Edible vegetable is among products collected from the forest by indigenous people of the island (Hastin et al., 2013). Vegetable for consumption are also found cultivated in home gardens and sold in local markets (Kodoh et al., 2009; Kamarul et al., 2012; Hastin et al., 2013; Foo et al., 2016; Jualang et al., 2016). The significant of vegetable is not just as food sources, but also important for cultures, income generation, and scientific studies (Kodoh et al., 2009; Normiadilah and Noriah, 2012; Hastin et al., 2013; Wan Izatul, 2013; Solehah and Nasuruddin, 2014). Besides fulfilling nutritional needs, some bioactive compounds in 
vegetable are even used as medicinal plants, believed to be effective in preventing and curing illness. For example, polyphenols that can be found in plant-based food are the biggest group of phytochemicals (Tsao, 2010). Intake of polyphenols diet could help prevent many illnesses that are related to free radical damage such as neurodegenerative diseases, cancers, and cardiovascular-related illnesses (Tsao, 2010). The vegetable also served a commercial purpose in generating income, as vegetable can be harvested from the local forest and traded in markets or produce in industrial scale farm for larger markets import (Kodoh et al., 2009; Hastin et al., 2013; Foo et al., 2016).

There is a practice of eating fresh and raw vegetable, and these eaten raw vegetable are called "ulam" (Faridah et al., 2006). "Ulam" is a generic Malay word for freshly eaten plant, and the closest English translation for word "ulam" is salad. It is often coherent with raw, fresh, crunchy, leafy, boiled, steamed, soft textured side dish or appetizer, eaten with a dip made of fish sauce, chilies paste, shrimp paste, or dressing made of lime, salt, and chilies (Normiadilah and Noriah, 2012). Another Malay word that can be used as equivalent to salad is "kerabu". "Kerabu" is a term coined for a type of dish, when prepared with a mixture of many ingredients including lots of vegetable (Normiadilah and Noriah, 2012). The term "ulam" could invoke many definitions, as it is not necessarily fulfilling the botanical definition of herbs, or vegetable, or limited to part of the plant, but rather the usage or how it is administered (Normiadilah and Noriah, 2012). For example, cucumber or Cucumis sativus is a fruit, however many have consumed fresh cut cucumber as salad or "ulam", and "rebung" or bamboo shoot (Bambusa spp.) is a growing appendage of seed germination, it is commonly eaten as traditional vegetable (Kulip, 1996; Normiadilah and Noriah, 2012). The former fulfilled the basic definition of fruit, which is having seeds wrapped inside watery flesh and peel, meanwhile, the latter fulfilled the basic definition of vegetable, which is producing shoot as a vegetative body for growth, and both are treated as vegetable. The consumption of "ulam" also includes the consumption of edible mushrooms (Wong and Chye, 2009), which belongs to another separate kingdom, Fungi. In Borneo, administering edible mushrooms as vegetable are common among the community whose livelihood surrounded by nature (Chong et al., 2007; Abdullah and Rusea, 2009). Initiating question of "what is ulam?" could lead to a tangle of jargons and semantic confusion. Nevertheless, this paper aims to compile the plant, fruits, mushrooms, seaweed, which have been consumed or treated as traditional vegetable or "ulam" in Borneo and discussed the phytochemicals as well as the potential health benefits of the "ulam" as food and medicine.

\section{Materials and methods}

Google Scholar, Google, ScienceDirect, and using Research Gate portal databases were searched for this review. Studies on traditional salad food, indigenous vegetable, edible mushrooms, and seaweed which were reported from 1997 to 2017 for Borneo were selected and analysed. The keywords used were shuffled combination of "Borneo", "ethnics", "diversity", "ulam", "indigenous vegetable", "Sabah", "Sarawak", "Kalimantan", "Brunei", "ethnobotany", and "sayur". The literature found and used consisted of journals, proceedings, department reports, chapter in book, and thesis. These references are written in English, and some selected publications are in Bahasa Indonesia.

\section{Ethnobotany and health benefit of traditional vegetable of Borneo}

\subsection{The variety of traditional vegetable salad and wild edible plants in Borneo.}

There is no exclusive study on traditional vegetable salad or "ulam" of Borneo, in previous efforts, the study of traditional vegetable was often incorporated together in ethnobotany survey, medicinal plant research, phytochemical study, traditional ethnobotanical knowledge (TK) survey, and socio-cultural study. All these fields of research are rather broad and complex. Nevertheless, this work attempted to review "ulam" used in Borneo according to areas, Sabah, Sarawak, Brunei, and Kalimantan.

In Sabah, among the most common local vegetable eaten raw as salad food are, Carica papaya, Centella asiatica, Clinacanthus nutans, Cosmus caudatus, Etlingera spp., Eryngium foetidum, Ipomoea batatas, Kaempfaria galanga, Morinda citriflora, Ocimum tenuiflorum, Peperomia pellucida, Parkia sp., Phaleria papuana, and Piper sp. (Kulip, 1996; Kulip, 2003; Kulip, 2005; Foo et al., 2016; Jualang et al., 2016). All these plants are easily obtained from local traders in the weekly market and can be found planted in the home garden or cultivated in farmland (Kulip, 2005; Foo et al., 2016). A survey conducted among Kadazandusun and Murut communities of Crocker Range Park and surrounding area found that $82 \%$ of the respondents are dependent on the forest to collect their supply of wild vegetable, and another $18 \%$ collected to sell the wild vegetable in the local market (Noweg et al., 2003). The most popular to be collected as vegetable are bamboo shoots, $45.96 \%$ from all collected wild vegetable, and they are low herbaceous plants from dry area (19.88\%). Young shoots of two bamboo species, locally known as "buluh betung" or Dendrocalamus asper and "buluh bukit" or Bambusa sp. were consumed raw or briefly 
boiled as salad food. Meanwhile, there were notable species of ferns consumed as vegetable, namely; Acrosticum aureum, Cyclosorus aridus, Diplazium esculentum, Helminthostachys zeylanica, Nephrolepis acutifolia, and Stenochaleana palustris. Out of these six species, only Cyclosoru saridus or locally known as paku and Nephrolepis acutifolia or "paku putih", were consumed raw as salad (Noweg et al., 2003). The detail of edible fern preparation methods and part used is shown in Table 1.

Other than consuming forest vegetable as ulam, Sabahan also consumed dried seaweed namely; Kappahycus alvarezzii and Eucheuma denticulatum as salad food (Sade et al., 2006; Varaippan and Mikio, 2008). The seaweed cultivation is commonly practiced in the east coastal district of Semporna, Kunak, Lahad Datu, and other districts in the west coast of Sabah, such as Kota Belud, Kudat, and Kota Marudu (Sade et al., 2006). Seaweed is believed and proven as nutritional dietary resources, and consisting antioxidant properties (Sade et al., 2006; Vairappan and Mikio, 2008; Fisal et al., 2012; Ling et al., 2014). The demographics of these aforementioned coastal districts are mainly the heartland of Bajau people, Sama-Bajau in the West Coast, and Sea -Bajau or Semporna-Bajau in the East Coast. Thus, the practice of eating raw seaweed is related to the dietary habit of the Bajau, especially Semporna-Bajau who are known historically as the skilful seafaring tribe (Table 1). List of wild edible ferns consumed by Kadazandusun and Murut communities of Crocker Range Park and the surrounding area, in Sabah.
Meanwhile, in Sarawak, ethnobotanical works have been scientifically carried out since 1980 s and at the same time, Sarawak Department of Agriculture had been doing substantial and collective research efforts in cultivation and domestication of Sarawak indigenous wild vegetable (Voon and Kueh, 1999; Mertz, 2007). A survey was conducted among Iban of Lubok Antu, Sri Aman on wild vegetable cultivated in farm trial and found five wild vegetable species valued important as local diet and have agronomic and economic value. Two of these wild vegetables are ferns, two gingers, and another one is a member of Acanthaceae family (Metrz, 2007). The list of these selected cultivated wild vegetable by Iban community of Lubok Antu, Sri Aman is as in Table 2. Voon and Kueh (1999) enumerated a total of 46 of indigenous edible wild plants of Sarawak, including leafy vegetable, fruits, shoots, and inflorescent. The study also includes the inventory of Sarawak wild fruits which are known as a source of nutrients by locals and also have the potential for commercialisation. The list of Sarawak indigenous leafy vegetable and fruit vegetable is as presented in Table 3 .

A study of the usage of fruits and wild vegetable among Dayak Kenyah community in East Kalimantan found sprout of Cyperus bancanus and Imperata cylindirca being consumed as "lalapan" or "lalap". "Lalapan" or "lalap" can be generally translated as salad in Bahasa Indonesia (Hendra, 2002). The community also consumed wild ferns as vegetable, namely; Cyathea contaminans or "paku tiang", Diplazium sp., Nephrolepis bisserata, and Stenochlaena sp. (Hendra, 2002). Hastin

Table 1. List of wild edible ferns consumed by Kadazandusun and Murut communities of Crocker Range Park and surrounding area, in Sabah.

\begin{tabular}{|c|c|c|c|c|}
\hline Family & Scientific name & $\begin{array}{c}\text { Recorded local } \\
\text { name }\end{array}$ & Part consumed & Preparation method \\
\hline Athyriacaeae & Diplazium esculentum & Pakis & Young shoots, leaves bud & Fried with garlic and anchovies \\
\hline Blechnaceae & Stenochlaena palustris & Lambiding & Young shoots, leaves bud & $\begin{array}{l}\text { Fried with garlic, anchovies or } \\
\text { shrimp paste }\end{array}$ \\
\hline Oleandraceae & *Nephrolepis acutifolia & Paku putih & Young shoots, leaves bud & Boiled, fried, eaten as salad \\
\hline Ophioglossaceae & Helminthostachys zeylanica & Arukaruk & Young shoots, leaves bud & $\begin{array}{l}\text { Cooked, fried with garlic and } \\
\text { anchovies }\end{array}$ \\
\hline Pteridaceae & Acrosticum aureum & Paku besar & Young curled bud, leaves & Fried \\
\hline Theylypteridaceae & *Cyclosorus aridus & Paku & Young shoots & $\begin{array}{l}\text { Eaten as salad, simmered briefly in } \\
\text { boiling water }\end{array}$ \\
\hline
\end{tabular}

*Fern species that have been consumed as traditional vegetable salad (ulam) by the community. Adopted from Noweg et al. (2003)

Table 2. Selected wild vegetable cultivated in farm plot by Iban in Lubok Antu, Sri Aman, Sarawak.

\begin{tabular}{cccl}
\hline Family & Scientific name & Recorded local name (Iban) & Part used \\
\hline Acanthaceae & Pseuderanthum bornense & Gelabak & Young/older leaves as spinach \\
Athyriacaeae & Diplazium esculentum & Pakuikan & Young fronds fried or boiled \\
Blechnaceae & Stenochlaena palustris & Kemiding & Young fronds fried or boiled \\
Zingiberaceae & Etlingera elatior & Kechala & Heart of young shoots, flower buds, fruits. Condiment for \\
Zingiberaceae & Etlingera punicea & Tepus & Heart of young shoots, flower buds, fruits. \\
\hline
\end{tabular}

Adopted from Mertz (2007) 
Table 3. Sarawak indigenous leafy vegetable and fruit vegetable.

\begin{tabular}{|c|c|c|c|}
\hline Family & Scientific name & Vernecular name & Part used \\
\hline Amaranthaceae & Alternanthera sessilis & Keremak & Leaves \\
\hline Arecaceae & Eleiodoxa conferta & Asam paya & Fruits \\
\hline Asteraceae & Sonchus sp. & Anak mambung & Leaves \\
\hline Asteraceae & Vernonia sp. & Rinyuh & Leaves \\
\hline Asteraceae & Erechtites hieraciifolius & $\begin{array}{l}\text { Sawi } \\
\text { Rusa }\end{array}$ & Leaves \\
\hline Athyriacaeae & Diplazium esculentum & Paku ikan & Leaves, young fronds \\
\hline Begoniaceae & Begonia chlorsticia & Riang batu & Leaves \\
\hline Blechnaceae & Stenochlaena plaustris & Miding & Leaves, young fronds \\
\hline Blechanceae & Blechnum orientale & Paku kelindang & Leaves, young fronds \\
\hline Costaceae & Costa speciosus & Sempulang padi & Leaves \\
\hline Cucurbitaceae & Cucumis sativus & Timun dayak & Fruits \\
\hline Euphorbiaceae & Acalypha sp. & Sepang & Leaves \\
\hline Euphorbiaceae & Baccaurea lanceota & Empang & Fruits \\
\hline Fabaceae & Pithecellobium lobatum & Jering & Beans \\
\hline Fabaceae & Parkia javanicus & Petai & Beans \\
\hline Flacourtiaceae & Pangium edule & Kepayang & Leaves, fruits \\
\hline Gnetaceae & Gnetum gnemon & Melinjau & Leaves, fruits \\
\hline Gnetaceae & Gnetum sp. & Tegang & Leaves \\
\hline Lythraceae & Sonneratia caseolaris & Pedada & Fruits \\
\hline Menispermaceae & Pycnarrhena tumetacta & Tubu & Leaves \\
\hline Moraceae & Ficus sp. & Ara & Fruits \\
\hline Myrsinaceae & Embelia sp. & Kacam rumpang & Leaves \\
\hline Myrtaceae & Eugenia sp. & Bungkang & Leaves \\
\hline Olacaceae & Scorodocarpus borneensis & Sindu & Leaves \\
\hline Oleandraceae & Nephrolepis acutifolia & Paku kubuk & Leaves, young fronds \\
\hline Ophioglossaceae & Helminthostachy ssp. & Tongkat langit & Leaves \\
\hline Passifloraceae & Passiflora foetida & Letup & Leaves \\
\hline Portulacaceae & Portulaca oleracea & Germi & Leaves \\
\hline Smilacaceae & Smilax barbata & Merudang & Leaves \\
\hline Solanaceae & Solanum ferox & Terung bulu & Fruits \\
\hline Solanaceae & Solanum lasiocarpum & Terung dayak & Fruits \\
\hline Solanaceae & Solanum torvum & Terung pipit & Fruits \\
\hline Urticaceae & Leucosyke capitellata & Teh Kampung & Leaves \\
\hline Verbenaceae & Premna cordifolia & Singkil & Leaves \\
\hline Vitaceae & Cissus sp. & Akar kura & Leaves \\
\hline Vitaceae & Vitis triloba & Lakom & Fruits \\
\hline
\end{tabular}

Adopted from Voon and Kueh (1999).

et al. (2011) had surveyed local vegetable used by Dayak people of Central Kalimantan. They found a total of 42 types of local vegetable consumed by Dayak people, which were prepared as stir-fried dishes, soups, or eaten as lalap. The list of local vegetable from Central Kalimantan is shown in Table 4, fungus is also included in this list. In local name, generic term for fungi is "kulat".

The Dayak of Central Kalimantan's preparation methods for eating wild vegetable varies from stir-fried, light soup, "jahu" or coconut milk added dish, and freshly eaten. Irawan et al. (2006) noted, "paria" leaves (Momordica charantia) and "senggau" (Solanum torvum) are plainly boiled as a "lalap" or salad. These delicacies are often served as side dish, eaten with hot chilies dip and the main dish.

Compare to Sabah, Sarawak, and Kalimantan,
Brunei Darussalam has the least documentation or literature available that studied on ulam or wild vegetable. Nevertheless, there was a proximate analysis of Artocarpus odoratissimus or "tarap" from Brunei Darussalam by Tang et al. (2013). It is also noted that consuming "tarap", which is a fruit tree, is not limited to eating its fleshy aril, the tarap's flower is also used as ingredients in salad or eaten as vegetable (Tang et al., 2013). There was also older ethnobotanical work which involved Dusun community in Merimbun village, Tutong, Brunei by Bernstein et al. (1997). The plot survey in ethnobotanical work found that the Dusun relied significantly on rice farming, and at the same time they also cultivated fruit trees and vegetable (known as "umbus" or "sancam") in their orchard and gathered wild edible leafy plants from forest, especially ferns. There are five types of ferns consumed among the Dusun of Merimbun; "gerajai", "paku”, "limputong", "engkubuk", 
Table 4. List of local vegetable consumed by Dayak people of Central Kalimantan.

\begin{tabular}{|c|c|c|c|}
\hline Family & Scientific name & Recorded local name (Dayak) & Part used \\
\hline Alismatacaeae & Limnocharis flava & Genjer & Plant body, young leaves \\
\hline Amarylidaceae & Crinum asiaticum & Bakung & Inner trunk \\
\hline Anacardiaceae & Spondiaspinnata & Dawen kedondong & Young leaves \\
\hline Araceae & Colocasia esculentum & Lantar kujang & Young plant \\
\hline Arecaceae & Bambusa spinose & Ujau puring manis/ujau betung & Shoot \\
\hline Arecaceae & Calamus sp. & Singkah/ Rotan & Shoot \\
\hline Arecaceae & Cocos nucifera & Singkah enyuh & Shoot \\
\hline Arecaceae & Elaeis guinensis & Singkah undus & Shoot \\
\hline Asteracaeae & Vernonia cinerea & Segau/Sansawi & Leaves \\
\hline Asteraceae & Lactuca indika & Singkah potok/kenyem & Shoot \\
\hline Auricaulariaceae & Auriacaularia auricaula & Kulat bitak & Main body \\
\hline Blenachnaceae & Stenochlaena palustris & Kalakai & Young leaves \\
\hline Bromeliaceae & Ananas comosus & Kanas & Young fruit \\
\hline Cucurbitaceae & Cucumis sativus & Tantimun batu & Fruit \\
\hline Cucurbitaceae & Cucurbita moschata & Baluh bahenda & Flower, fruit, young leaves. \\
\hline Cucurbitaceae & Momordica charantia & Dawen paria & Young leaves \\
\hline Cucurbitaceae & Cucumis sativus & Dawen mantimun & Young leaves \\
\hline Cucurbitaceae & Gymnopetalum sp. & Kanjat & Young fruit \\
\hline Dioscoreaceae & Dioscorea aculeate & Uwiturus & Tuber \\
\hline Euphorbiaceae & Carica papaya & Mantela & Flower, young fruit, young leaves. \\
\hline Euphorbiaceae & Manihot esculenta & Dawen jawau & Young leaves \\
\hline Euphorbiaceae & Cnesmone javanica & Lampinak/dawen kalamenga & Leaves \\
\hline Hygrophoraceae & Hygrocybeconica & Kulat tiaw & Main body \\
\hline Leguminosae & Mimosa pudica & Uruk mahamen & Young leaves \\
\hline Liliaceae & Alliums choenoprasum & Bawang suna & Bulbs, leaves \\
\hline Malvaceae & Abelmochus esculentum & Jagung Belanda & Fruit \\
\hline Marattiaceae & Christensenia aesculifolia & Teken parei & Young leaves \\
\hline Musaceae & Musa paradasiaca & Pisang & Inflorescence, immature fruit, inner trunk. \\
\hline Phyllanthaceae & Sauropus androgynous & Dawen katuk & Young leaves \\
\hline Physalacriaceae & Oudemansiella sp. & Kulat enyak & Main body \\
\hline Pleurotaceae & Pleurotus sp. & Kulat danum & Main body \\
\hline Pluteaceae & Volvariellla volvacea & Kulat baputi & Main body \\
\hline Poacaeae & Cymbopogon citratus & Sarai & Plant body \\
\hline Pteridaceae & Ceratopteris thalictroides & Bajei & Young leaves \\
\hline Rubiaceae & Nauclea $s p$ & Dawen taya & Young leaves \\
\hline Schizophyllaceae & Schizophyllum commune & Kulat keritip & Main body \\
\hline Solanaceae & Solanum ferox & Rimbang masem & Fruit \\
\hline Solanaceae & Solanum mammosum & Terung tanteloh & Fruit \\
\hline Solanaceae & Solanum torvum & Senggau/Terung pipit & Fruit \\
\hline Zingiberaceae & Curcuma zanthorrhiza & Kambang herda & Flower \\
\hline
\end{tabular}

Modified from Hastin et al. (2011).

and "kuban" (Bernstein et al., 1997). Besides gathering ferns, they also planted some gingers and palm species, namely Daemonorops fissa, Licuala paludosa, and Licuala spinosa (Bernstein et al., 1997).

Other than Dusun tribe, Orang Ulu or Penan is also another minority nomadic hunter-gatherer tribe in southern area of Brunei Darussalam. Their livelihood depends on nomadic hunting and gathering activity, and preparing sago starch from Eugeissona utilis, a wild palm, and known as "nangah" by the Penan (Voeks and Sercombe, 2000). The Penan is also involved in barter trading with Dusun in Sukang village, which is in the interior of Brunei (Voeks and Sercombe, 2000). In 2017, Farazimah et al. studied total phenolic, total flavonoid contents, and antioxidant activity for eight species of "ulam" from Brunei. Four from eight studied ulam species namely; Litsea elliptica, Cosmos caudatus, Centella asiatica, Curcuma longa, have shown good antioxidant activity. Even though there is lack of ethnobotanical documentation on ulam in Brunei Darussalam, the work on natural product chemistry of traditional fruits and vegetable is progressing (Tang et al., 2013; Farazimah et al., 2017)

\subsection{Similarity of traditional vegetable salad consumed in Borneo}

It is apparent that fern species are consumed as traditional vegetable in different parts of Borneo. Even though there is high ethnic diversity in Borneo, fern species are consumed by many indigenous groups such as Kadazandusun and Murut communities in Sabah, Iban people in Sarawak, Dayak in East Kalimantan, and Dusun Merimbun in Brunei Darussalam (Bernstein et al., 
1997; Voon and Kueh, 1999; Hendra, 2002; Noweg et al., 2003; Hastin et al., 2011). Ferns are known by their generic local names as "paku" or "pakis" (Malay).

Stenochlaena palustris is an all Bornean traditional vegetable; its young reddish fronds are harvested and consumed all over part of Borneo. This fern species is also well spread throughout Southeast Asia region, and known by many local names such as "lambiding", "lemiding", "midin", "kemiding", "kalakai", and "pakis merah" (Noweg et al., 2003; Chai et al., 2012). It is believed to have nutritional and antioxidant values (Yim et al., 2009). Other than Stenochlaeana palustris, Diplazium esculentum is also a common edible fern that has been consumed as ulam in many parts of Borneo. Locally, Diplazium esculentum is called "paku ikan" or "pakis" (Bernstein et al., 1997; Voon and Kueh, 1999; Hendra, 2002; Noweg et al., 2003).

Beside ferns, fungi are also consumed as traditional salad or ulam by people of Borneo (Wong and Chye 2008; Abdullah and Rusea 2009; Yim et al., 2009). However, the species of edible mushrooms varied and identified as edible mushrooms and are locally known by their generic name as "kulat" or "cendawan" (Malay).
Schizophyllum commune or "kodop" is a popular edible mushroom in Sabah and is known as "kulat keritip" in Kalimantan, and as "cendawan sisir" in Sarawak (Abdullah and Rusea, 2009; Hastin et al., 2011). Fruit of Solanum torvum and leaves of Momordica charantia have been treated as traditional vegetable in Kalimantan, Sabah, and Sarawak (Voon and Kueh, 1999; Kulip, 2003; Irawan et al., 2006; Hastin et al., 2011). Similarity of ulam consumed in Borneo is shown in Table 5.

\subsection{Chemical composition, nutritional value, and health} benefit potential of selected traditional vegetable of Borneo

Scientific studies have shown that vegetable have nutritional benefits, and some are claimed to have medicinal value. Polyphenols from fruits and vegetable are able to prevent further damage by reactive oxygen species (ROS) (Tsao, 2010). Subsequently, obtaining natural antioxidants from fruits and vegetable could help in lowering risk of having illness caused by oxidative stress (Wen et al., 2012; Abu Bakar et al., 2015). The diseases are cardiovascular disease, cancer, diabetes, dementia, and Alzheimer (Faridah et al., 2006; Liliwirianis et al., 2011; Shirazi et al., 2014). Vegetable

Table 5. Similarity of traditional vegetable or "ulam" consumed in Borneo.

\begin{tabular}{|c|c|c|c|c|}
\hline Type & Species name & Recorded local names & Locality & References \\
\hline \multirow{4}{*}{ Ferns } & Diplazium esculentum & Paku ikan, pakis & $\begin{array}{l}\text { Bn, Kn, Sbh, } \\
\text { Swk }\end{array}$ & $\begin{array}{l}\text { Bernstein et al. (1997); Voon and } \\
\text { Kueh (1999); Hendra (2002); Noweg } \\
\text { et al. }(2003)\end{array}$ \\
\hline & Nephrolepis acutifolia & Paku putih, kubuk, engkubuk & Bn, Sbh, Swk. & $\begin{array}{l}\text { Bernstein et al. (1997); Voon and } \\
\text { Kueh (1999); Hendra (2002); Noweg } \\
\text { et al. (2003) }\end{array}$ \\
\hline & Nephrolepis bisserata & Paku & $\mathrm{Bn}, \mathrm{Kn}, \mathrm{Sbh}$ & $\begin{array}{l}\text { Bernstein et al. (1997); Hendra } \\
\text { (2002); Kulip (2003) }\end{array}$ \\
\hline & Stenochlaena palustris & $\begin{array}{l}\text { Lemiding, lambiding, midin, } \\
\text { kemiding, kalakai }\end{array}$ & $\begin{array}{l}\text { Bn, Kn, Sbh, } \\
\text { Swk }\end{array}$ & $\begin{array}{l}\text { Bernstein et al. (1997); Voon and } \\
\text { Kueh, 1999; Noweg et al. (2003); } \\
\text { Hastin et al. (2011) }\end{array}$ \\
\hline \multirow{6}{*}{ Mushrooms } & Auricaularia spp. & $\begin{array}{l}\text { Kulat tepik (Iban), kulat perk } \\
\text { (Melanau), kulat bitak (Dayak) }\end{array}$ & Kn, Swk & $\begin{array}{l}\text { Abdullah and Rusea (2009); Hastin et } \\
\text { al. (2011) }\end{array}$ \\
\hline & Cookeinasul cipes & Kulat mangkuk & Sbh, Swk & Abdullah and Rusea (2009) \\
\hline & Galiella rufa & Mata kerbau, mata rusa & Sbh, Swk & Abdullah and Rusea (2009) \\
\hline & Hygrocybe spp. & Kulat tiaw, kulat buah & Kn, Swk & $\begin{array}{l}\text { Abdullah and Rusea (2009); Hastin et } \\
\text { al. (2011) }\end{array}$ \\
\hline & Schizophyllum commune & $\begin{array}{l}\text { Kulat keritip, cendawan sisir, } \\
\text { kodop (Dusun) }\end{array}$ & Kn, Sbh, Swk & $\begin{array}{l}\text { Abdullah and Rusea (2009); Hastin et } \\
\text { al. (2011) }\end{array}$ \\
\hline & Termitomyces aurantiacus & Kulat tahun & Sbh, Swk & Abdullah and Rusea (2009) \\
\hline Fruits & Solanum torvum & $\begin{array}{l}\text { Terung pipit, terung tanteloh, } \\
\text { lintahun (Murut), senggau }\end{array}$ & Kn, Sbh, Swk & $\begin{array}{l}\text { Voon and Kueh (1999); Kulip (2003); } \\
\text { Irawan et al. (2006); Hastin et al. } \\
\text { (2011) }\end{array}$ \\
\hline \multirow{2}{*}{ Leaves } & Manihot esculenta & $\begin{array}{l}\text { Dawenjawau (Dayak), lui } \\
\text { (Murut) }\end{array}$ & $\mathrm{Kn}, \mathrm{Sbh}$ & Kulip (2003); Hastin et al. (2011) \\
\hline & Sauropus androgynus & Dawen katuk, Sayur manis & $\mathrm{Kn}, \mathrm{Sbh}$ & $\begin{array}{l}\text { Hastin et al. (2011); Muhammed and } \\
\text { Muthu, (2015) }\end{array}$ \\
\hline \multirow{2}{*}{ Flower buds } & Etlingera elatior & Kechala (Iban), bungakantan & Sbh, Swk & $\begin{array}{l}\text { Voon and Kueh (1999); Ng et al. } \\
\text { (2012) }\end{array}$ \\
\hline & Etlingera punicea & Tepus, tetubuh, tuhau (Dusun) & Sbh, Swk & $\begin{array}{l}\text { Voon and Kueh (1999); Noweg et al. } \\
\text { (2003) }\end{array}$ \\
\hline
\end{tabular}

Bn: Brunei Darussalam; Kn: Kalimantan; Sbh: Sabah, Swk: Sarawak 
have also been used as a folk medicine to treat microbial related illness, e.g. malaria, and common fever. These traditional practices by indigenous people on utilizing plant resources to treat diseases have been supported by the discovery of anti-microbial, and anti-inflammatory properties in vegetable (Suhaini et al., 2015; Jualang et al., 2016). For example, crude methanolic extract of Gleichenia truncate, a type of local fern that has been consuming as traditional vegetable by people in Penampang, Sabah, are reported able to suppress the in vivo development of Plasmodium berghei, a parasite that causes malaria disease (Suhaini et al., 2015).

In 2017, five species of indigenous leafy vegetable from Bintulu, Sarawak, namely; Scorodocarpus borneensis, Pangium edule, Gnetum gnemon, Dracaena gracilis, and Helminthostachys zeylanica were selected and analyzed to determine their mineral contents (Asyira et al., 2016). Pangium edule is suggested as a good source of calcium since it contains the highest concentration of calcium $(466.66 \mathrm{mg} / 100 \mathrm{~g})$ among the evaluated species. Calcium is an important element that helps regulate nerve and muscle regulation, it is also vital for teeth and bone growth (Soetan et al., 2009). Meanwhile, Scorodocarpus borneensis (343.86 mg/100 g) and Dracaena gracilis $(342.69 \mathrm{mg} / 100 \mathrm{~g})$ could be the alternative resources of phosphorus for patient with kidney problem. The phosphorus content per $100 \mathrm{~g}$ for both species does not exceed the recommended phosphorus intake for chronic kidney patient $(<700 \mathrm{mg}$ / day) (González-Parra et al., 2012; Asyira et al., 2016). However, kidney patients should always consult physician for suitable diet that cater their need and health condition.

Etlingera is a member of ginger family or Zingiberaceae. Several species in Etlingera group are known as traditional plants that have been consumed widely in Borneo as fresh vegetable condiment or as pickled side dish. Etlingera elatior is known as "kechala" among Iban in Sarawak, or ginger torch or "bunga kantan" (Malay) in Peninsular Malaysia. Extracts of Etlingera elatior have been reported to have antibacterial and antioxidant activity. Meanwhile, Etlingera punicea is known as "tepus" (Iban) in Sarawak or "tuhau" (Dusun), in Sabah. The phytochemical composition and nutritional value of Etlingera elatiorhas been investigated by $\mathrm{Ng}$ et al. (2012) and found that it contains higher phenolic, flavonoid, and potassium contents than green leafy wild vegetable. Therefore, Etlingera is a reliable as antioxidant resource for those who consume it regularly. Crude extracts from rhizome of Etlingera belalongensis and Etlingera velutina that were collected from Tawau Hills Park, Sabah, displayed cytotoxic activity against MDA-MB-231 cancer cell line
(Sabli et al., 2012). The total phenolic and total flavonoid content of these Etlingera species as shown in Table 6. In 2012, Vairappan et al. reported, essential oil extracted from five species of Etlingera collected in Borneo exhibits anti-bacterial activity against four strains of food pathogenic bacteria: Staphylococcus aureus (HP0808), Staphylococcus sp. (HP1008), Streptococcus pyrogenes (HP1208) and Salmonella enteritidis (HP0608), and anti-cancer activity against breast cancer cell (MCF-7). Scientific data on the effectiveness of Etlingera spp. as a potential source of herbal medicine could be further studied to preclinical and clinical level in order to add more credible value to the species and traditional knowledge from Borneo.

Table 6. Total phenolic and total flavonoid content of Etlingera belalongensis and Etlingera velutina collected from Tawau Hills Park, Sabah.

\begin{tabular}{cccc}
\hline Species & Part & $\begin{array}{c}\text { Total phenolic } \\
\text { (mg GAE/g) }\end{array}$ & $\begin{array}{c}\text { Total flavonoid } \\
\text { (mg CE/g) }\end{array}$ \\
\hline $\begin{array}{c}\text { Etlingera } \\
\text { belalongensis }\end{array}$ & Rhizome & $17.07 \pm 0.32$ & $3.77 \pm 0.15$ \\
\multirow{2}{*}{ Etlingera velutina } & Stem & $10.07 \pm 0.25$ & $2.57 \pm 0.15$ \\
& Rhizome & $25.03 \pm 0.46$ & $7.63 \pm 0.06$ \\
& Stem & $5.30 \pm 0.10$ & $2.80 \pm 0.20$ \\
\hline
\end{tabular}

Adopted from Sabli et al. (2012).

Meanwhile, the fern that is commonly consumed as traditional vegetable and salad in Borneo, Stenochlaena palustris, is also utilized for its medicinal benefit. Chai et al. (2012) reported the total polyphenol, flavonoid, hydroxycinnamic acid and anthocyanin contents, as well as radical scavenging, ferric reducing and metal chelating activities of the extracts of Stenochlaena palustris. It also has potential as a good source of phosphorus and potassium. Relatively, mature sterile frond $(51.69 \pm 1.28 \mathrm{mg} \mathrm{GAE} / \mathrm{g})$ has the highest total polyphenols compare to young sterile frond, young fertile frond, and mature fertile frond. Moreover, mature sterile frond $(58.05 \pm 0.30 \mathrm{mg} \mathrm{CE} / \mathrm{g})$ is also reported to contain higher total flavonoid content than young sterile frond, young fertile frond, and mature fertile frond. Five new $O$-acylated flavonol glycosides have been isolated from Stenochalaena palustris leaves collected from Papua New Guinea, and among these compounds are found to have significant anti-bacterial contribution (Liu et al., 1999). However, there is a lack of study to further investigate the effectiveness of Bornean Stenochlaena palustris extract by using bioassay cell line and in vivo animal study. The Penan people in Sarawak have been utilizing this species as a dietary vegetable for new mother during postpartum confinement to regain energy. Meanwhile, the decoction of the leaves is consumed orally, and poultice is rubbed on the head to reduce high fever (Chai et al., 2012). The detail of the total polyphenols content of Stenochlaena palustris is as shown in Table 7. 
Table 7. Total contents of polyphenols, flavonoids, hydroxycinnamic acids and anthocyanins of the leaf extracts of Stenochlaeana palustris from Sarawak.

\begin{tabular}{lcccc}
\hline \multicolumn{1}{c}{ Extract } & $\begin{array}{c}\text { Total polyphenols } \\
(\mathrm{mg} \mathrm{GAE} / \mathrm{g})\end{array}$ & $\begin{array}{c}\text { Total flavonoids } \\
(\mathrm{mg} \mathrm{CE} / \mathrm{g})\end{array}$ & $\begin{array}{c}\text { Total hydroxycinnamic acids } \\
(\mathrm{mg} \text { CE/g) }\end{array}$ & $\begin{array}{c}\text { Total anthocyanins } \\
(\mathrm{mg} \text { CGE/100 g) }\end{array}$ \\
\hline Young sterile frond & $42.58 \pm 1.01$ & $46.59 \pm 0.07$ & $32.24 \pm 0.16$ & $51.32 \pm 2.95$ \\
Mature sterile frond & $51.69 \pm 1.28$ & $58.05 \pm 0.30$ & $48.80 \pm 0.18$ & $2.56 \pm 0.80$ \\
Young fertile frond & $41.68 \pm 0.19$ & $57.21 \pm 0.41$ & $38.93 \pm 0.41$ & $2.67 \pm 0.77$ \\
Mature fertile frond & $18.78 \pm 0.51$ & $18.95 \pm 0.26$ & $15.26 \pm 0.12$ & $2.67 \pm 0.33$ \\
\hline
\end{tabular}

Adopted from Chai et al. (2012).

Cosmos caudatus or in Malay is known as "ulam raja", is a well-known traditional vegetable salad in Malay food culture and this species has also been administered and consumed as traditional vegetable in Borneo (Fatimah et al., 2012; Liliwirianis et al., 2012; Bachok et al., 2014; Jualang et al., 2016; Farazimah et al., 2017). It is noted that "ulam raja" offers health benefits to the consumers, include providing a protective mechanism against oxidative damage and anti-aging (Fatimah et al., 2012; Liliwirianis et al., 2012; Farazimah et al., 2017). Liliwirianis et al. (2012) investigated the phytochemical content of Cosmos caudatus and reported that the leaves of the species contain alkaloid, saponin, steroid, phenolic, flavonoid, and terpenoid. The carotenoid compounds found in "ulam raja" are; lutein, $\beta$-carotene, and zeaxanthin (Fatimah et al., 2012). Moreover, Jualang et al. (2016) found that Cosmos caudatus $(83.09 \pm 3.22)$ has high scavenging performance and comparable to catechin $(90.96 \pm 1.09 \%)$. Ethanolic extract of Cosmos caudatus that was obtained from Kota Belud, Sabah, showed activity against P388 murine leukemia cell (Lee and Vairappan, 2011). Safe food product or natural additive could be developed from or using essential oil of Cosmos caudatus, this is due to potential of its essential oil against several food pathogens (Lee and Vairappan, 2011). The constituents of essential oils from Cosmos caudatus is as described in Table 8 .

Table 8. Relative concentration of constituents in Cosmos caudatus essential oil collected from Kota Belud, Sabah.

\begin{tabular}{lc}
\hline \multicolumn{1}{c}{ Component } & Relative concentration (\%) \\
\hline (E)-Ocimene & 5.64 \\
2,6-Dimethyl-1,3,5,7-octatetraene & 4.69 \\
$\alpha$-Copaene & 0.84 \\
$\beta$-Elemene & 3.3 \\
Caryophyllene & 9.73 \\
$\alpha$-Humulene & 2.28 \\
$\gamma$-Muurolene & 0.75 \\
$\gamma$-Cadinene & 33.29 \\
Bergamotene & 2.92 \\
$\beta$-Selinene & 0.57 \\
Bicyclogermacrene & 3.17 \\
$\alpha$-Farnesene & 6.06 \\
$\delta$-Cadinene & 2.02 \\
\hline
\end{tabular}

Adopted from Lee and Vairappan (2011).
The fruit of Solanum torvum, or locally known as "terung pipit", "terung tanteloh", "senggau" (Dayak), "lintahun" (Murut) has been consumed as traditional vegetable, condiment in cooking, and as well as eaten fresh. The fruit of Solanum torvum contains isoflavonoidsulfate and steroidal glycoside, which are anti-viral agents (Arthan et al., 2002). Effective antioxidant properties in the fruit extract also contribute as cardio protective function (Jaiswal, 2012). Steroidal glycoside was also found in the shoot and root of Solanum torvum (Yahara et al., 1996). However, the record of consumption of shoot and root of this plant by local people in Borneo is not available. Meanwhile, the aqueous extract of the leaves contains anti-inflammatory and pain reducing properties, as the extract was effectively halting unpleasant syndrome induced by acetic acid in rats (Ndebia et al., 2007). Other than that, oral administration of methyl caffeate isolated from fruit of Solanum torvum had shown dose-dependent antihyperglycemic effect through in vivo study (Jaiswal, 2012). The Murut people in Sabah, use Solanum torvum fruit as a condiment for cooking meat, the Lundayeh, another indigenous people in Sipitang district, Sabah, and Dayak in Kalimantan, consume the fruit fresh (Kulip et al., 2000; Kulip, 2003; Hastin et al., 2011). These local tribes of Borneo can obtain direct health benefit of the plant through their traditional diet practice.

Clinacanthus nutans is a functional vegetable that locally known in Sabah, as "lindau" (Dusun) or "Sabah Snake Grass" or "belalai gajah" and is called as "dandang gendis" in Indonesia (Lusia et al., 2015). Traditionally, this species has been consumed as vegetable, and serve double functions as traditional medicine, as the fresh leaves could be made into paste or poultice, and use to treat rashes on the skin, insect bite, and snake bite (Lusia et al., 2015). Due to its potential as traditional medicine, in 2015, Clinacanthus nutans fresh leaves that were collected from Ranau, Sabah, was made into fermented and unfermented tea leaves. These herbal drinks were later investigated for antioxidant assays, and the potential of unfermented tea is higher than fermented tea (reference). The total phenolics content of Clinacanthus nutans herbal teas as shown in Table 9. This innovation offers more option on how local vegetable can be consumed, which is not just eaten as 
Table 9. Total phenolics content of Clinacanthus nutans herbal tea, collected from Ranau, Sabah.

\begin{tabular}{cccc}
\hline \multirow{2}{*}{$\begin{array}{c}\text { Type of Clinacanthus nutans } \\
\text { herbal tea }\end{array}$} & $\begin{array}{c}\text { Infusion } \\
\text { Time }\end{array}$ & $\begin{array}{c}\text { Freeze dried } \\
\text { (mg TAE/L) }\end{array}$ & $\begin{array}{c}\text { Microwave oven dried } \\
\text { (mg TAE/L) }\end{array}$ \\
\cline { 2 - 4 } & 1 & $132.60 \pm 18.57$ & $131.24 \pm 8.71$ \\
Unfermented & 2 & $140.08 \pm 12.23$ & $143.92 \pm 18.76$ \\
& 5 & $143.96 \pm 14.44$ & $143.56 \pm 8.95$ \\
& 10 & $162.48 \pm 12.58$ & $164.48 \pm 14.37$ \\
& 15 & $158.48 \pm 15.11$ & $146.80 \pm 11.7$ \\
Fermented & 1 & $160.68 \pm 5.49$ & $177.80 \pm 19.10$ \\
\hline 2 & $88.56 \pm 4.40$ & $101.48 \pm 15.79$ \\
& 5 & $96.12 \pm 15.55$ & $111.2 \pm 13.59$ \\
& 10 & $105.88 \pm 14.74$ & $137.08 \pm 18.41$ \\
& 15 & $108.72 \pm 8.94$ & $136.92 \pm 7.43$ \\
& 20 & $110.40 \pm 7.68$ & $134.52 \pm 26.38$ \\
& & & $105.60 \pm 16.02$ \\
\hline
\end{tabular}

Adopted from Lusia et al. (2015)

fresh leaves, but also made into home beverages, and at the same time still maintain the health benefit of the product (Lusia et al., 2015).

Antioxidants are microconstituents present in the diet that could delay or halt lipid oxidation and are also functional in scavenging free radical (Szôllôsi and Varga, 2002). Prevention of lipid oxidation by antioxidant properties could help protect cardiac tissue (Jaiswal, 2012). Many flavonoids such as quercetin, luteolin and catechins are better antioxidants than the antioxidant nutrients like vitamin $\mathrm{C}$, vitamin $\mathrm{E}$ and $\mathrm{B}$ carotene (Zhonghong et al., 1999). Numerous investigators have shown that foods containing phytocompounds with antioxidant potential act as a strong protective agent against chronic illness risks, including cancer and cardiovascular diseases (Osman et al., 2004). Potential of local edible fern species as herbal medicine to treat tropical disease like malaria, could also open more opportunity for other species of edible ferns to be studied for their biomedical benefit (Suhaini et al., 2015). Commonly, these are several highlighted species that have been consumed as traditional vegetable salad in Borneo and scientifically proven as good resources of nutrition, e.g. minerals, carbohydrates, antioxidant with high phenolic and flavonoid contents. In addition, they also indicated beneficial potentials for health as antimicrobial, anti-inflammatory, anti-hyperglycemic, and anti-cancer agents.

\section{Conclusion}

Despite the ongoing scientific interest on traditional vegetable especially in the exploration for its nutritional, pharmaceutical, and nutraceutical values, there are still many undiscovered parts of Borneo that are not known for the types of traditional vegetable salad or "ulam" consumed by the highly diverse indigenous ethnics. The concrete scientific medicinal values for traditional vegetable salad or "ulam" of Borneo in term of preparation, administration, quality, and safety have yet to be established. A comprehensive research approach on this domestic source of nutrition in Borneo and also how it affects livelihood, agriculture, socio-economy, wellness, and health of the Bornean shall be planned, as well as the establishment of collaboration between academics, research institutions, local authorities, local communities, and pharmaceutical companies. Research strategy must also consider the new technologies in screening, advancement in natural product biotechnology, and use of artificial intelligence in formulating pharmaceutical products. Commercial products by small to medium enterprises (SME) that utilize local traditional vegetable, e.g. herbal tea, herbal supplements, food additive, food flavouring, should be developed by considering effectiveness and safety of the products, sustainability of the selected plant species, the sensory attribute of the vegetable food products, and also access benefit sharing of the profit with the local people as the direct stakeholder of biodiversity in Borneo. All these will put more values on traditional vegetable of Borneo as beneficial biological resources and shall be able to place Borneo as a significant hub for nutraceutical, bioprospecting, and herbal medicine research.

\section{Conflict of interest}

The authors declare no conflict of interest.

\section{Acknowledgement}

Thank you to all parties involved in the preparation of this manuscript. Special thanks to Malaysia Ministry of Education (Department of Higher Education) under FRGS scheme (K 009) as well as Universiti Malaysia 
Sabah (UMS) and Universiti Tun Hussein Onn Malaysia (UTHM) for their kind assistance.

\section{References}

Abdullah, F. and Rusea, G. (2009). Documentation of inherited knowledge on wild edible fungi from Malaysia. Blumea-Biodiversity, Evolution and Biogeography of Plants, 54(1-1), 35-38. https:// doi.org/10.3767/000651909X475996

Abu Bakar, M.F., Abdul Karim, F. and Perisamy, E. (2015). Comparison of phytochemicals and antioxidant properties of different fruit parts of selected Artocarpus species from Sabah, Malaysia. Sains Malaysiana, 44(3), 355-363. https:// doi.org/10.17576/jsm-2015-4403-06

Arthan, D., Svasti, J., Kittakoop, P., Pittayakhachonwut, D., Tanticharoen, M. and Thebtaranonth, Y. (2002). Antiviral isoflavonoidsulfate and steroidal glycosides from the fruits of Solanum torvum. Phytochemistry, 59(4), 459-463. https:// doi.org/10.1016/S0031-9422(01)00417-4

Asyira, S.A., Sarbini, S.N.S. and Harah, Z.M. (2016). Mineral content of five indigenous leafy vegetable from Bintulu market, Sarawak, Malaysia. Journal of Medicinal Herbs and Ethnomedicine, 2, 26-35.

Barton, H. and Paz, V. (2007). Subterranean diets in the tropical rain forests of Sarawak, Malaysia. In Denham, T., Iriarte, J., and Vrydaghs, L. (eds) Rethinking agriculture. Archaeological and ethnoarchaeological perspectives, p. 50-77. London: Routledge.

Bernstein, J.H., Ellen, R. and Antaran, B.B. (1997). The use of plot surveys for the study of ethnobotanical knowledge: A Brunei Dusun example. Journal of Ethnobiology 17(1), 69-96.

Brodie, J. and Giordano, A. (2011). Small carnivores of the Maliau Basin, Sabah, Borneo, including a new locality for Hose's Civet Diplogalehosei. Small Carnivore Conservation, 44, 1-6.

Chai, T.T., Panirchellvum, E., Ong, H.C. and Wong, F.C. (2012). Phenolic contents and antioxidant properties of Stenochlaena palustris, an edible medicinal fern. Botanical Studies, 53(4), 439-446.

Fatimah, A.M.Z., Norazian, M.H. and Rashidi, O. (2012). Identification of carotenoid composition in selected "ulam" or traditional vegetable in Malaysia. International Food Research Journal, 19(2), 527 530.

Farazimah, Y., Malai, H.S.A.H., Norhayati, A., Aida, M.B. and Mohamed, A.M. (2017). The screening of anti-oxidant activity, total phenolic and flavonoid contents of local ulam-ulaman of Brunei
Darussalam. International Conference of Natural Products. Malaysia: Malaysian Natural Product Societt (MNPS).

Faridah, A., Lajis, N.H., Israf, D.A., Khozirah, S. and Kalsom, Y.U. (2006). Antioxidant and nitric oxide inhibition activities of selected Malay traditional vegetable. Food Chemistry, 95(4), 566-573. https:// doi.org/10.1016/j.foodchem.2005.01.034

Fisal, A., Sulaiman, M.R., Saimon, W., Yee, C.F. and Matanjun, P. (2016). Proximate compositions and total phenolic contents of selected edible seaweed from Semporna, Sabah, Malaysia. Borneo Science, 31, 74-83.

Foo, J., Mohamad, A.L., Omar, M. and Amir, A.A. (2016). Utilitarian tumbuhan ubatan di tamu Pantai Barat Sabah (Utilitarian of medicinal plants in tamu (local market) of West Coast, Sabah). GeografiaMalaysian Journal of Society and Space, 12(12), 99112.

González-Parra, E., Gracia-Iguacel, C., Egido, J. and Ortiz, A. (2012). Phosphorus and nutrition in chronic kidney disease. International Journal of Nephrology, 2012, $1-5 . \quad$ https:// doi.org/10.1155/2012/597605

Hastin, E.N.C.C., Susi, K. and Yula, M. (2011). Studi etnobotani sayuran indigenous (local) Kalimantan Tengah. In Seminar Nasional: Reformasi Pertanian Terintegrasi Menuju Kedaulatan Pangan. Indonesia: Fakultas Pertanian Universiti Trunojoyo.

Hendra, M. (2002). Pemanfaatan tumbuhan, buahbuahan dan sayuran liar oleh suku Dayak Kenyah, Kalimantan Timur. Makalah Pengantar Falsafah Sains, Bogor: Institut Pertanian Bogor.

Hitchner, S.L. (2010). Heart of Borneo as a 'Jalan Tikus': Exploring the links between indigenous rights, extractive and exploitative industries, and conservation at the World Conservation Congress 2008. Conservation and Society, 8(4), 320-340. https://doi.org/10.4103/0972-4923.78148

Irawan, D., Wijaya, C.H., Limin, S.H., Hashidoko, Y., Osaki, M. and Ici, P.K. (2006). Ethnobotanical study and nutrient potency of local traditional vegetable in Central Kalimantan. Tropics, 15(4), 441-448. https:// doi.org/10.3759/tropics. 15.441

Jaiswal, B.S. (2012). Solanum torvum: a review of its traditional uses, phytochemistry and pharmacology. International Journal of Pharma and Bio Sciences, 3(4), 104-111.

Jualang, A.G., Adznila, E. and How, S.E. (2016). In vitro bioactivities and phytochemicals content of vegetable from Sabah, Malaysia. Borneo Science, 37 (1), 37-53. 
Kamarul, M.M., Langgat, J., Dahnil, M.I. and Noor Fzlinda, F. (2012). Articles: visitor motivation, expectation and satisfaction of local cultural event in Sabah. A case study of tamu besar Kota Belud. International Journal of Culture and Tourism Research, 5(1), 39-50.

Chong, K.S., Chye, F.Y., Lee, J.S. and Atong, M. (2007). Nutritional properties of some edible wild mushrooms in Sabah. Journal of Applied Sciences, 7 (15), 2216-2221. https://doi.org/10.3923/ jas.2007.2216.2221

Kodoh, J., Mojiol, A.R. and Lintangah, W. (2009). Some common non-timber forest products traded by indigenous community in Sabah, Malaysia. Journal of Sustainable Development, 2(2), 148-152. https:// doi.org/10.5539/jsd.v2n2p148

Kulip, J. (1996). A survey of indigenous plants used for food and medicine by the Kadazandusun ethnic in Tambunan, Sabah, East Malaysia. Borneo Research Council Fourth Biennial Conference of the Borneo Research Council. Brunei Darussalam, Bandar Seri Begawan: University of Brunei Darussalam.

Kulip, J. (2003). An ethnobotanical survey of medicinal and other useful plants of Muruts in Sabah, Malaysia. Telopea, 10(1), 81-98. https:// doi.org/10.7751/telopea20035608

Kulip, J. (2005). Similarity of medicinal plants used by two native communities in Sabah, Malaysia. ISHS Acta Horticulturae 675: III WOCMAP Congress on Medicinal and Aromatic Plants., Vol. 1, p. 81-85. USA: Acta Horticulturae. https://doi.org/10.17660/ ActaHortic.2005.675.10

Kulip, J., Majawat, G. and Kulik, J. (2000). Medicinal and other useful plants of the Lundayeh community of Sipitang, Sabah, Malaysia. Journal of Tropical Forest Science, 12(4), 810-816.

Lee, T.K. and Vairappan, C.S. (2011). Antioxidant, antibacterial and cytotoxic activities of essential oils and ethanol extracts of selected South East Asian herbs. Journal of Medicinal Plants Research, 5(21), 5284-5290.

Liliwirianis, N.M., Zain, W.Z.W.M., Kassim, J. and Karim, S.A. (2011). Premilinary studies on phytochemical screening of ulam and fruit from Malaysia. Journal of Chemistry, 8(S1), S285-S288. https://doi.org/10.1155/2011/464595

Liu, H., Orjala, J., Sticher, O. and Rali, T. (1999). Acylated flavonol glycosides from leaves of Stenochlaena palustris. Journal of Natural Products, 62(1), 70-75. https://doi.org/10.1021/ np980179f

Lusia, M.B., Hasmadi, M., Zaleha, A.Z. and Fadzelly,
A.M. (2015). Effect of different drying methods on phytochemicals and antioxidant properties of unfermented and fermented teas from Sabah Snake Grass (Clinacanthus nutans Lind.) leaves. International Food Research Journal, 22(2), 661.

Mertz, O. (2007). The potential of wild vegetable as permanent crops or to improve fallows in Sarawak, Malaysia. In Cairns, M. (Ed.), Voices from the Forest: Integrating Indigenous Knowledge into Sustainable Upland Farming, p. 73-86. London: Routledge.

Muhammed, N. and Muthu, T.A. (2015). Indigenous people and their traditional knowledge on tropical plant cultivation and utilization: A case study of Murut communities of Sabah, Borneo. Journal of Tropical Resources and Sustainable Science, 3, 117128.

Ndebia, E.J., Kamgang, R. and Nkeh-Chungag Anye, B.N. (2007). Analgesic and anti-inflammatory properties of aqueous extract from leaves of Solanum torvum (Solanaceae). African Journal of Traditional, Complementary, and Alternative Medicines, 4(2), 240-244. https://doi.org/10.4314/ajtcam.v4i2.31214

Ng, X.N., Chye, F.Y. and Mohd Ismail, A (2012). Nutritional profile and antioxidative properties of selected tropical wild vegetable. International Food Research Journal, 19(4), 1487-1496.

Normiadillah, A. and Noriah, O. (2012). The relationship between plants and the Malay culture. ProcediaSocial and Behavioral Sciences, 42, 231-241. https:// doi.org/10.4314/ajtcam.v4i2.31214

Noweg, T., Abdullah, A.R. and Nidang, D. (2003). Forest plants as vegetable for communities bordering the Crocker Range National Park. ASEAN Review of Biodiversity and Environmental Conservation (ARBEC), January-March 2003, 1-18.

Sabli, F., Mohamed, M., Rahmat, A., Ibrahim, H. and Abu Bakar, M.F. (2012). Antioxidant properties of selected Etlingera and Zingiber species (Zingiberaceae) from Borneo Island. International Journal of Biological Chemistry, 6(1), 1-9. https:// doi.org/10.3923/ijbc.2012.1.9

Sade, A., Ali, I., Ariff, M. and Raduan, M. (2006). The seaweed industry in Sabah, East Malaysia. Journal of Southeast Asian Studies, 11(1), 97-107.

Shirazi, O.U., Khattak, M.A.K., Shukri, N.A.M. and Nasyriq, M.N. (2014). Determination of total phenolic, flavonoid content and free radical scavenging activities of common herbs and spices. Journal of Pharmacognosy and Phytochemistry, 3(3), 104-108. 
Soetan, K.O., Olaiya, C.O. and Oyewole, O.E. (2010). The importance of mineral elements for humans, domestic animals and plants-A review. African Journal of Food Science, 4(5), 200-222.

Solehah, I. and Nassuruddin, M.G. (2014). Traditional Malay healing practices: Expressions of cultural and local knowledge. Procedia-Social and Behavioral Sciences, 140, 291-294. https://doi.org/10.1016/ j.sbspro.2014.04.422

Suhaini, S., Liew, S.Z., Norhaniza, J., Lee, P.C., Jualang, G., Embi, N. and Hasidah, M.S. (2015). Antimalarial and anti-inflammatory effects of Gleichenia truncata mediated through inhibition of GSK3 3 . Tropical Biomedicine, 32(3), 419-433.

Szôllôsi, R. and Varga, I.S. (2002). Total antioxidant power in some species of Labiatae (Adaptation of FRAP method). Acta Biologica Szegediensis, 46(34), 125-127.

Tang, Y.P., Linda, B.L.L. and Franz, L.W. (2013). Proximate analysis of Artocarpus odoratissimus (tarap) in Brunei Darussalam. International Food Research Journal, 20(1), 409-415.

Tsao, R. (2010). Chemistry and biochemistry of dietary polyphenols. Nutrients, 2(12), 1231-1246. https:// doi.org/10.3390/nu2121231

Vairappan, C.S. and Mikio, K. (2008). Nutritional properties, antioxidant potential and antibacterial activity of two edible seaweeds, Kappaphycus alvarezii and Eucheuma denticulatum (Gigartinales, Rhodophyta). Malaysian Journal of Science, 27(2), 53-65.

Vairappan, C.S., Nagappan, T. and Palaniveloo, K. (2012). Essential oil composition, cytotoxic and antibacterial activities of five Etlingera species from Borneo. Natural product communications, 7(2), 1934578X1200700233. https:// doi.org/10.1177/1934578X1200700233

Voeks, R.A. and Sercombe, P. (2000). The scope of hunter-gatherer ethnomedicine. Social Science and Medicine, 51(5), 679-690. https://doi.org/10.1016/ S0277-9536(00)00012-5

Voon, B.H. and Kueh, H.S. (1999). The nutritional value of indigenous fruits and vegetable in Sarawak. Asia Pacific Journal of Clinical Nutrition, 8(1), 24-31. https://doi.org/10.1046/j.1440-6047.1999.00046.x

Wan Izatul, A.W.T. (2013). Protection of the associated traditional knowledge on genetic resources: beyond the Nagoya Protocol. Procedia-Social and Behavioral Sciences, 91, 673-678. https:// doi.org/10.1016/j.sbspro.2013.08.468

Wen, K.C., Fan, P.C., Tsai, S.Y., Shih, I. and Chiang, H.M. (2012). Ixora parviflora protects against UVB- induced photoaging by inhibiting the expression of MMPs, MAP kinases, and COX-2 and by promoting type I procollagen synthesis. Evidence-Based Complementary and Alternative Medicine, 2012, 111. https://doi.org/10.1155/2012/417346

Wong, J.Y. and Chye, F.Y. (2009). Antioxidant properties of selected tropical wild edible mushrooms. Journal of Food Composition and Analysis, 22(4), 269-277. https://doi.org/10.1016/ j.jfca.2008.11.021

Yahara, S., Yamashita, T., Nozawa, N. and Nohara, T. (1996). Steroidal glycosides from Solanum torvum. Phytochemistry, 43(5), 1069-1074. https:// doi.org/10.1016/S0031-9422(96)00396-2

Yim, S.H., Chye, Y.F., Ho, K.S. and Ho, W.C. (2009). Phenolic profiles of selected edible wild mushrooms as affected by extraction solvent, time and temperature. Asian Journal of Food and AgroIndustry, 2(3), 392-401.

Zhonghong, G., Huang, K., Yang, X. and Xu, H. (1999). Free radical scavenging and antioxidant activities of flavonoids extracted from the radix of Scutellaria baicalensis Georgi. Biochimica et Biophysica Acta (BBA)-General Subjects, 1472(3), 643-650. https:// doi.org/10.1016/S0304-4165(99)00152-X 